\title{
Trp63 is regulated by STAT5 in mammary tissue and subject to differentiation in cancer
}

\author{
Shahin Assefnia ${ }^{1, *}$, Keunsoo Kang ${ }^{2,3, *}$, Svenja Groeneveld ${ }^{1,4}$, Daisuke Yamaji ${ }^{2}$, \\ Sarah Dabydeen', Ahmad Alamri ${ }^{1,5}$, Xuefeng Liu ${ }^{6}$, Lothar Hennighausen ${ }^{2}$ \\ and Priscilla A Furth ${ }^{1,7}$
}

'Department of Oncology, Lombardi Comprehensive Cancer Center, Georgetown University, 3970 Reservoir Road NW, Research Building, Room 520A, Washington, District of Columbia 20057, USA

${ }^{2}$ Laboratory of Genetics and Physiology, National Institute of Diabetes and Digestive and Kidney Diseases, National Institutes of Health, 8 Center Drive, Bethesda, Maryland 20892-0822, USA

${ }^{3}$ Department of Microbiology, Dankook University, Cheonan 330-714, Republic of Korea

${ }^{4}$ Department Pharmazie, Ludwig-Maximilians-Universität München, München, Germany

${ }^{5}$ College of Medical Sciences, King Khalid University, Abha, Saudi Arabia

Departments of ${ }^{6}$ Pathology and ${ }^{7}$ Medicine, Lombardi Comprehensive Cancer Center, Georgetown University, 3970 Reservoir Road NW, Research Building, Room 520A, Washington, District of Columbia 20057 USA

*(S Assefnia and K Kang contributed equally to this work)

Correspondence should be addressed to P A Furth

Email paf3@georgetown.edu

\begin{abstract}
Transformation-related protein 63 (Trp63), the predominant member of the Trp53 family, contributes to epithelial differentiation and is expressed in breast neoplasia. Trp63 features two distinct promoters yielding specific mRNAs encoding two major TRP63 isoforms, a transactivating transcription factor and a dominant negative isoform. Specific TRP63 isoforms are linked to cell cycle arrest, apoptosis, survival, and epithelial mesenchymal transition (EMT). Although TRP63 overexpression in cultured cells is used to elucidate functions, little is known about Trp63 regulation in normal and cancerous mammary tissues. This study used ChIP-seq to interrogate transcription factor binding and histone modifications of the Trp63 locus in mammary tissue and RNA-seq and immunohistochemistry to gauge gene expression. $\mathrm{H} 3 \mathrm{~K} 4 \mathrm{me} 2$ and $\mathrm{H} 3 \mathrm{~K} 4 \mathrm{me} 3$ marks coincided only with the proximal promoter, supporting RNA-seq data showing the predominance of the dominant negative isoform. STAT5 bound specifically to the Trp63 proximal promoter and Trp63 mRNA levels were elevated upon deleting Stat5 from mammary tissue, suggesting its role as a negative regulator. The dominant negative TRP63 isoform was localized to nuclei of basal mammary epithelial cells throughout reproductive cycles and retained in a majority of the triplenegative cancers generated from loss of full-length Brca1. Increased expression of dominant negative isoforms was correlated with developmental windows of increased progesterone receptor binding to the proximal Trp63 promoter and decreased expression during lactation was correlated with STAT5 binding to the same region. TRP63 is present in the majority of triple-negative cancers resulting from loss of Brca 1 but diminished in less differentiated cancer subtypes and in cancer cells undergoing EMT.
\end{abstract}

Key Words

- mammary gland

- gene regulation

- molecular genetics

- oncogene

- neoplasia
Endocrine-Related Cancer (2014) 21, 443-457 http://erc.endocrinology-journals.org DOI: 10.1530/ERC-14-0032
(C) 2014 Society for Endocrinology Printed in Great Britain
Published by Bioscientifica Ltd 


\section{Introduction}

The transformation-related protein 63 (Trp63) gene encodes two major isoforms, which are encoded by distinct mRNAs originating from two unique promoters (Yao \& Chen 2012). The transactivating (TA) isoform carries an $\mathrm{N}$-terminal acidic domain that is lacking in the more abundant dominant negative $(\Delta \mathrm{N})$ isoform. Both $\mathrm{TA}$ and $\Delta \mathrm{N}$ transcripts undergo splicing events, generating additional isoforms, which differ at their $\mathrm{COOH}$ terminus (Murray-Zmijewski et al. 2006). TRP63 along with TRP73 is a member of the TRP53 family of transcription factors. It binds and transactivates target genes of TRP53 (Yang et al. 1998). TRP63 is required for epithelial tissue development, including mammary anlagen as well as limb and craniofacial development (Mills et al. 1999, Yang et al. 1999). TATrp63 isoforms are expressed before $\Delta \mathrm{NTrp63}$ isoforms during mouse embryogenesis (Yao \& Chen 2012). High levels of TRP63 are found in basal cells of many tissues including mammary myoepithelial (Yang \& McKeon 2000, Nylander et al. 2002, Sbisa et al. 2006, Truong et al. 2006, Forster et al. 2014, Yallowitz et al. 2014). Stem cells of epithelial tissues such as colon, urinary bladder, and prostate and mammary glands express TRP63 where it appears to be essential for maintaining the proliferative and regenerative abilities of the stem cell pool in stratified epithelial structures (Pellegrini et al. 2001, Senoo et al. 2007, Pignon et al. 2013) and glandular mammary tissue (Yallowitz et al. 2014). TRP63 has been reported to regulate cell survival (Liefer et al. 2000, Senoo et al. 2004, Pietsch et al. 2008, Yallowitz et al. 2014), epithelial mesenchymal transition (EMT; Lindsay et al. 2011, Oh et al. 2011, Tran et al. 2013), and paracrine signaling in epidermis (Barton et al. 2010) and mammary gland (Forster et al. 2014). Different TRP63 isoforms have the ability, at least in overexpressing tissue culture cells, to regulate gene transcription and exhibit distinct and similar functions (Dohn et al. 2001, Koster et al. 2007). DNTRP63 isoforms have been reported to have longer half-life than TATRP63 isoforms (Yao \& Chen 2012).

For a large percentage of target genes, $\triangle$ NTRP63 appears to be the primary regulator of expression, at least in epidermis (Barton et al. 2010). Consistent with this concept, in triple-negative breast cancer cell lines, both $\mathrm{TA}$ and $\Delta \mathrm{N}$ isoforms have the ability to positively regulate caspase 1 and their co-expression is positively correlated with survival (Celardo et al. 2013). TA isoforms can prevent $\triangle$ NTRP63 isoforms from up-regulating expression of oncogenic miR155, expression of which is linked to tumor growth and migration (Mattiske et al. 2013). TATRP63 and its target Sharp1 inhibit metastasis of triple-negative breast cancer cells via degradation of hypoxia-induced factors (Montagner et al. 2012, Piccolo et al. 2013). Expression of $\triangle$ NTRP63 $\alpha$ inhibits EMT triggered by the $\Delta$ NTRP63 $\gamma$ isoform in normal mammary epithelial cells (MECs; Lindsay et al. 2011) and constrains EMT in bladder cancer cells (Oh et al. 2011). However, it has also been reported that $\triangle$ NTRP63 $\alpha$ promotes EMT in normal keratinocytes (Tran et al. 2013). While it is known that TRP63 can be expressed in many types of cancer, the percentage of cancers within each type expressing TRP63 varies (Yao \& Chen 2012). In mammary tissue, TRP63 has been shown to contribute to maintenance of parityidentified MECs (PI-MECs; Yallowitz et al. 2014) and TRP63 haploinsufficiency reduces pregnancy-promoted ERBB2 tumorigenesis in transgenic mice expressing activated ERBB2 (Yallowitz et al. 2014).

Post-pubertal development of mammary tissue is typified by hormonally regulated cycles of epithelial cell proliferation, function and apoptosis during estrus (Fata et al. 2001), pregnancy (Li et al. 1997, Schorr et al. 1999), lactation, and involution. During pregnancy, the prolonged proliferative phase triggered by estrogen and progesterone signaling is followed by relative quiescence with lactation, and apoptosis during involution correlated with phosphorylation and activation of STAT3. TRP63 in mammary myoepithelial cells is required for lobuloalveolar development during pregnancy (Forster et al. 2014) through controlling neuregulins 1 and 2 (Nrg1 and Nrg2) expression (Forster et al. 2014, Yallowitz et al. 2014). NRG1 is a paracrine factor expressed in mammary myoepithelial cells required for normal ERBB4 and STAT5 activation in luminal mammary epithelium (Forster et al. 2014). STAT5 activation in mammary luminal progenitor cells is required for normal lobuloalveolar development (Liu et al. 1997, Cui et al. 2004, Yamaji et al. 2009). TRP63 also contributes to regulating involution. Germline loss of one Trp63 allele is sufficient to increase rates of apoptosis during the first phase of involution, pointing to a role for TRP63 in promoting MEC survival (Yallowitz et al. 2014). By contrast, apoptosis and involution proceed normally when both Trp53 alleles are absent from the germline (Li et al. 1996). STAT3 has been reported to activate $\triangle$ NTRP63 $\alpha$ in Hep3B cells (Chu et al. 2008).

Published by Bioscientifica Ltd 
The presence of TRP63 is a proposed biomarker for basal cancer (Thike et al. 2010a, Shekhar et al. 2013) but not all investigations concur (Buckley et al. 2011, Thike et al. 2013). TRP63, cytokeratin 5 (KRT5), and smooth muscle actin (ACTA2) are expressed coordinately in normal basal mammary myoepithelial cells but are not invariably synchronously expressed in human breast cancers (Laakso et al. 2005, Jumppanen et al. 2007). Two different basal-like (BL) cancer subtypes are recognized, with BL2 but not BL1 demonstrating TRP63 expression with a poorer response to neoadjuvant chemotherapy as compared with BL1 (Lehmann et al. 2011, Masuda et al. 2013). In one study, higher TRP63 expression levels were positively correlated with brain metastasis (Shao et al. 2011). Positive staining for TRP63 can be used to differentiate intraductal papilloma from ductal carcinoma in situ (Moriya et al. 2009, Furuya et al. 2012). TRP63 is required for collective invasion of breast cancer organoids in $3 \mathrm{D}$ culture even if the cells used for culturing were acquired from primary tumors characterized as luminal rather than myoepithelial (Cheung et al. 2013).

Breast cancer susceptibility gene 1 (BRCA1) has been reported to increase transcription of the $\triangle \mathrm{NTrp63}$ isoforms in tissue culture cells (Buckley et al. 2011, Buckley \& Mullan 2012), while in vivo the presence of Trp63 expression is correlated with decreased expression of BRCA1 in basal-type breast cancers (Ribeiro-Silva et al. 2005). BRCA 1 and $\triangle$ NTRP 63 also co-regulate expression of NOTCH signaling in mammary basal cells and loss of NOTCH would result in increased expression of stem/progenitor pool, loss of markers for terminal differentiation, and simultaneous increase in basal markers (Buckley \& Mullan 2012). Women who carry BRCA1 mutations demonstrate an increase in the percentage of luminal progenitor cells, which are thought to represent precursor cells for BL triple-negative breast cancers (Lim et al. 2009). Triple-negative breast cancers are over-represented in women who carry BRCA1 mutations as compared with women who develop breast cancer without BRCA1 mutation (Ribeiro-Silva et al. 2005, Liu et al. 2008). This predilection is modeled in genetically engineered mice with a MEC-specific deletion of full-length Brca1 (Herschkowitz et al. 2007) allowing us to explore the impact of loss of full-length Brca1 on p63 expression levels.

This study now addressed the critical void in our understanding of in vivo regulation of Trp63 in mammary gland development and cancer. Specific objectives were to assess the impact of BRCA1 and understand the relationship with cancer cell differentiation and EMT.

\section{Materials and methods}

\section{Mouse models}

Female C57Bl/6 parental inbred and litter-mate control WT,

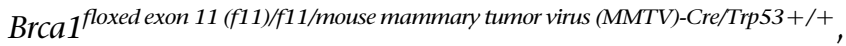
Brca1 $^{\text {f11/f11/MMTV-Cre/Trp53+/- }, B r c a 1} 1^{f 11 / W T / M M T V-C r e / T r p 53+/-}$, and Brca $1^{W T / W T / M M T V-C r e / T r p 53+/-/ t e t-o p-C Y P 19 A 1 / M M T V-r t T A}$ mice were identified by PCR (Jones et al. 2005; Transnetyx, Cordova, TN, USA), maintained in barrier zones in sterilized ventilated cages with corncob bedding and allowed to access water/chow ad libitum under $12 \mathrm{~h}$ light:12 h darkness cycles at Georgetown University (one to four mice per cage) or NIH (one mouse per cage). Mice were killed by $\mathrm{CO}_{2}$ narcosis and tissues were removed at necropsy following the guidelines approved by the GUACUC/NIHIACUC. Mammary glands were isolated from 2.5-, 6-, 8-, 10-, 16-, and 24-week-old mice that were nulliparous, pregnant (P; days 6 and 17 , calculated from the day of first appearance of vaginal plug), lactating (L; days 1 and 10), and undergoing involution (In; days 1,3 , and 7 ) ( $n=6$ nulliparous mice; $n=3$ qRT-PCR/immunohistochemistry (IHC); $n=3$, one mouse each estrus, proestrus, and diestrus; and $n=4$ P, L, and In mice). Estrous cycle stages were identified by vaginal cytology. Mammary cancers were isolated from 10- to 12-month-old nulliparous Brca1 f11/f11/ MMTV-Cre/Trp53+/- , Brca1 f11/WT/MMTV-Cre/Trp53+/- , and Brca1 ${ }^{W T / W T / M M T V-C r e / T r p 53+/-/ t e t-o p-C Y P 19 A 1 / M M T V-r t T A}$ mice $(n=12)$. Dissected abdominal mammary glands and minimum of one-third of tissue/cancer isolated from surrounding normal tissue were flash frozen in liquid nitrogen and a second/third were fixed in 10\% formalin and paraffin embedded.

\section{Histology and IHC}

Sections of $5 \mu \mathrm{m}$ were stained with hematoxylin and eosin (H\&E) or used for IHC: TRP63, MS-1081-P, 1:200 (Neomarkers, Fremont, CA, USA); TATRP63, sc-8608, 1:40; $\Delta$ NTRP63, sc-8609, 1:40; ESR1, sc-542, 1:750; PGR, sc-538, 1:750; Her2/neu, sc-284, 1:400 (Santa Cruz Biotechnology); single-stranded (ss) DNA, ALX-804-192, 1:10 (Alexis Biochemicals, Farmingdale, NY, USA); KRT5, PRB-160P, 1:1000 (Covance Lab, Princeton, NJ, USA); and ACTA2, 1184-1, 1:500 (Epitomics, Burlingame, CA, USA). Cancers were classified as triple-negative by gene expression array analyses (Herschkowitz et al. 2007) and/or by absence of ESR1, PGR, and HER2 $\leq 2+$ on IHC. IHC specificity was tested by omission of the primary

Published by Bioscientifica Ltd 
antibody. Digital images were generated using a Nikon Eclipse E800 Microscope using the Nikon DMX1200 Software (Nikon Instruments, Inc., Melville, NY, USA).

\section{Primary culture}

Primary mammary epithelial cancer cells were isolated (EpiCult-B (mouse), STEMCELL Technologies, Vancouver, CA, USA), divided, and cultured either to maintain expression of epithelial differentiation markers (E) as conditionally reprogrammed cells (Liu et al. 2012) or under conditions promoting expression of genes mediating EMT (EpiCult-B). Then they were removed and placed into the standard Gibco DMEM with 10\% fetal bovine serum and $1 \%$ Pen/Strep (Life Technologies). Cells were cultured at $37{ }^{\circ} \mathrm{C}$ with $5 \% \mathrm{CO}_{2}$ until they reached $85 \%$ confluency (48-72 h) and washed three times with $1 \times$ Gibco PBS (PBS) (Life Technologies). After washing, they were collected by scraping into $1.5 \mathrm{ml}$ Eppendorf tubes, washed again with $1 \times$ PBS, sedimented by centrifugation at $1000 \mathrm{~g}$ for $5 \mathrm{~min}$ followed by washing three times with $1 \times$ PBS, and frozen in liquid nitrogen.

\section{RNA isolation, cDNA synthesis, qRT-PCR, RT-PCR, RNA-seq, ChIP-seq, and statistical analyses}

For qRT-PCR, RNA was extracted using the Invitrogen PureLink Micro-to-Midi RNA Extraction Kit \#12183-018 and Qiagen Shredder Kit \#79654. Integrity was confirmed by the presence of $18 \mathrm{~S}$ and $28 \mathrm{~S}$ bands after agarose gel electrophoresis, and first-strand cDNA was synthesized. Expression levels of different Trp63 isoforms were determined using Mm00495788_m1 for total Trp63 (inventoried assay) and custom designed assays (Applied Biosystems): SApSh3T-EDS for TATrp63 (forward (F), CCCAGAGGTCTTCCAGCATATCT and reverse (R), TCAACTCGATGGGCTGTACTG); SApSh3D-SpC for $\triangle N \operatorname{Trp63}(\mathrm{F}, \mathrm{CCTGGAAAACAATGCCCAGACT}$ and R, AGGAGCCCCAGGTTCGT); SApSh3A-ESCR for $\operatorname{Trp} 63 \alpha$ (F, GGGCTGACCACCATCTATCA and R, GTCGGAACTGTTCAGGGATCTT); and SApSh3G-EDDp for Trp63 $\gamma$ (F, CAGCACCAGCACCTACTTCA and R, GCTCCACAAGCTCATTCCTGAA) with expression levels normalized to 18S (Hs99999901_s1). Means and S.E.M.s were analyzed using the Mann-Whitney $U$ test (GraphPad Software, San Diego, CA, USA). The $P$ values of $<0.05$ were considered statistically significant. Trp63, TATrp63, $\Delta \mathrm{N} \operatorname{Tr} p 63, \operatorname{Tr} p 63 \alpha$, $\operatorname{Trp63} \beta$, and Trp63 $\gamma$ RT-PCR was performed using published primers and conditions (Kurita et al. 2005) with Actb as control. For RNA-seq, RNA was isolated from frozen tissue or cell pellets (TRIzol, Invitrogen), purified (RNeasy Plus Mini Kit, Qiagen), and analyzed (Nanodrop, ThermoScientific (Wilmington, DE, USA) and Agilent Bioanalyzer 2100, Agilent Technologies, Inc. (Santa Clara, CA, USA)). Then RNA was converted to cDNA (SuperScript II, Invitrogen), sequencing libraries were prepared (TruSeq RNA Sample Preparation Kit, Illumina, San Diego, CA, USA) and analyzed (Nanodrop, Agilent Bioanalyzer 2100), and paired-end sequencing was performed (HiSeq 2000, Illumina). Read quality was determined using FastQC (http://www.bioinformatics.babraham.ac.uk/project/ fastqc), and contaminated adaptor portions were trimmed using Trim Galore (http://www.bioinformatics.babraham. ac.uk/project/trim_galore). Reads were aligned to mouse reference genome $\mathrm{mm} 9$ assembly, TopHat (Kim et al. 2013), and abundance of transcripts (fragments per kilobase of transcript per million mapped (FPKM) reads) was estimated. The mapped reads were analyzed using Cuffdiff (Trapnell et al. 2010) and visualized using the integrative genomics viewer (Robinson et al. 2011). GEO (http://www.ncbi.nlm.nih.gov/geo/) obtained ChIP-seq data (STAT5 and trimethylated lysine 4 histone H3 (H3K4me3) (GSE40930 and GSE31578) (Yamaji et al. 2013, Zhang et al. 2012); PGR (GSE42887) (Lain et al. 2013); dimethylated lysine 4 histone H3 (H3K4me2) (GSE25105) (Rijnkels et al. 2013); and RNA-seq (GSE37646)). ChIP-seq data were reanalyzed using the HOMER Software (http://homer.salk.edu/homer/) (Heinz et al. 2010, Kang et al. 2014).

\section{Results}

\section{Histone modifications and transcription factor binding at the Trp63 locus}

Regulatory features of the Trp63 gene in mouse mammary tissue were analyzed by scanning the locus for pertinent histone modifications and binding of transcription factors STAT5 and PGR, known to control gene expression in mammary epithelium, through mining ChIP- and RNAseq data from WT mammary gland (Zhang et al. 2012, Lain et al. 2013, Rijnkels et al. 2013, Yamaji et al. 2013, Kang et al. 2014; Fig. 1). H3K4me3 marks are indicative of active or poised promoters and H3K4me 2 marks have been associated with enhancers. Definitive H3K4me3 and H3K4me2 marks were observed only over the proximal promoter that yields $\Delta \mathrm{NTrp63}$ transcripts (Fig. 1A). H3K4me2 marks coincided with STAT5 binding at the proximal but not distal promoter. Binding of STAT5 at the same site in liver tissue supports the importance of this

Published by Bioscientifica Ltd. 
A

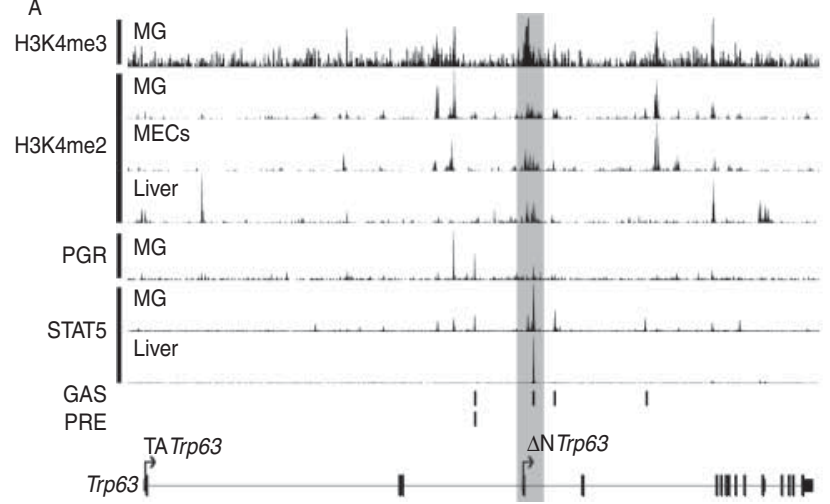

口 STAT5a $a^{-1-S T A T 5 b^{+/-}}$ STAT5a ${ }^{+/+}$STAT5 $b^{+/+}$
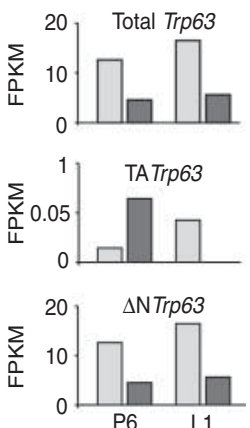

\section{Figure 1}

Histone modification and transcription factor binding to the Trp63 locus. (A) Available STAT5, PGR, H3K4me2, and H3K4me3 ChIP-seq data of mammary gland and liver were reanalyzed to unveil usage of proximal and distal Trp63 promoters. The seven tracks illustrated are (top to bottom): H3K4me3: MG, L1; H3K4me2: MG, L8; H3K4me2: MECs, nulliparousdiestrus; H3K4me2: liver, L8; and PGR: MG, ovariectomized nulliparous mice treated with E for $24 \mathrm{~h}$ then E+Pr for 6 h; STAT5a: MG, L1; and STAT5b: liver, nulliparous. (B) Bar graphs illustrating relative fragments per kilobase of

site. To explore a functional role for STAT5, RNA-seq was employed to analyze Trp63 levels in the presence of different numbers of Stat $5 a /$ Stat $5 b$ alleles. In WT mammary tissue, which is carrying intact Stat5a and Stat5b alleles, Trp63 expression amounted to 5 FPKM at both P6 and L1 (Fig. 1B). By contrast, Trp63 expression in the presence of only one Stat $5 b$ allele, which leads to an $\sim 90 \%$ reduction of STAT5a/STAT5b, was above 10 FPKM at both P6 and L1. Levels of $\Delta \mathrm{NTrp63}$ isoforms were much higher than those of TATrp63 isoforms as predicted by the ChIP-seq. This genetic experiment indicated that STAT5 is a negative regulator of Trp63. PGR binding at the proximal, but not distal, promoter coincided with H3K4me2 marks during lactation (Fig. 1A); however, in primary MECs from nulliparous mice, weak H3K4me2 marks coincided with PGR binding to the distal promoter (data not shown). Both STAT5 and PGR are expressed at high levels in luminal MECs while $\triangle$ NTRP63 is localized to basal myoepithelial cells (Fig. 2). This raises the possibility of STAT5 acting as a negative regulator of $\triangle$ NTRP63 in luminal cells.

\section{TRP63 and $\Delta$ NTRP63 were localized to basal MEC nuclei throughout reproductive development}

IHC for both TRP63 and $\triangle$ NTRP63 was performed in mammary tissue obtained from WT mice that were nulliparous, pregnant, lactating, or undergoing involution to determine if tissue or cellular localization changes during reproduction. KRT5 IHC was used as an transcript per million mapped (FPKM) reads of Trp63, TATrp63, and $\triangle \mathrm{NTrp63}$ in mammary glands from genetically engineered STAT5-deficient (STAT5 $^{-/-}$STAT5 $b^{+/-}$) (light gray) and WT $\left(\right.$STAT5a ${ }^{+/+}$STAT5 $b^{+/+}$) (dark gray) mice at P6 and L1 as estimated by RNA-seq. PGR, progesterone receptor; MG, mammary gland; MECs, mammary epithelial cells; GAS, $\gamma$-interferon-activated sequence; PRE, progesterone receptor-binding element; L1, lactation day 1; P6, pregnancy day 6; E, 17 $\beta$-estradiol (100 ng); and $\mathrm{Pr}$, progesterone $(2.5 \mu \mathrm{g})$.

independent marker for basal myoepithelial cells (Bankfalvi et al. 2004) and ssDNA IHC was performed to identify apoptotic cells (Frankfurt 2004). Basal myoepithelial cells were the most prominent cell type expressing TRP63 and $\Delta$ NTRP63 in all samples with nuclear localization throughout the cycle (Fig. 2). Both small (large panels) and large (insets) ducts and alveoli (large panels) were examined with localization of TRP63 and $\triangle$ NTRP63 to myoepithelial cells throughout. The relatively contiguous arrangement of basal myoepithelial cells expressing nuclear-localized TRP63 and $\Delta$ NTRP63 in mammary gland from nulliparous mice evolved to a more dispersed pattern in late pregnancy (p17) and lactation, returning to the pattern found in nulliparous mice by involution day 7 (In7). Myoepithelial cells appeared to undergo apoptosis during involution, defined by their location within tissue and the presence of TRP63, $\Delta$ NTRP63, and KRT5 staining in cells shed into the lumen. During the first 3 days of involution, apoptotic MECs are shed into the alveolar lumen (Schorr \& Furth 2000). Experiments indicated that patterns of Trp63 and $\Delta \mathrm{NTrp63}$ expression measured in total mammary gland are primarily derived from basal myoepithelial cells at all stages of reproductive development.

\section{Trp63 expression was regulated during mammary gland reproductive development}

Real-time RT-PCR was used to characterize expression levels of $\Delta$ NTrp63, total $\operatorname{Trp63}, \mathrm{TATr} \operatorname{Tr} 63, \operatorname{Trp} 63 \alpha$, and

Published by Bioscientifica Ltd 


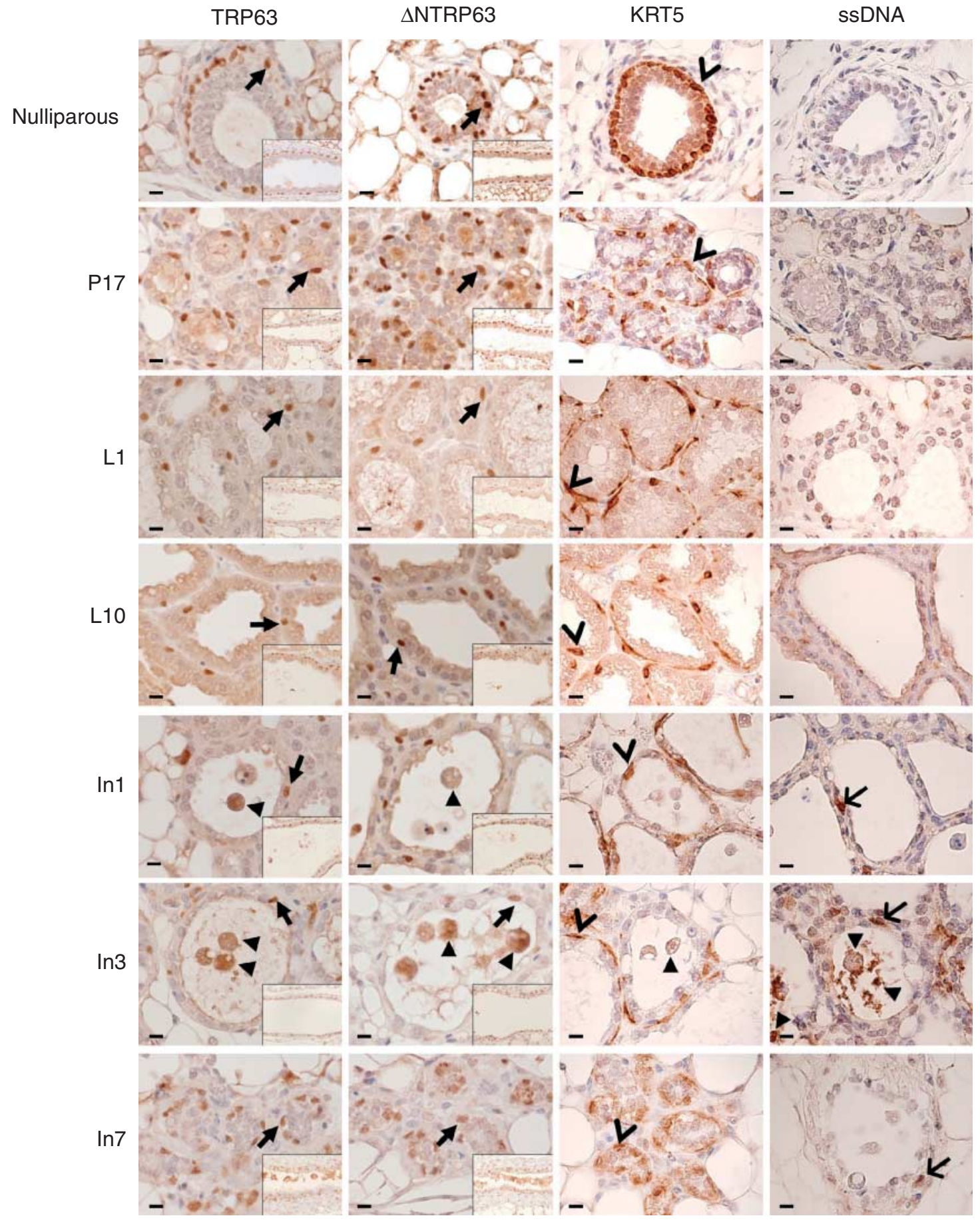

\section{Figure 2}

Immunohistochemical staining of distinct biological phases of postpubertal mammary gland development and involution. Representative images illustrating expression patterns of total TRP63, $\triangle$ NTRP63, KRT5, and single-stranded (ss) DNA in mammary gland from nulliparous, pregnancy day 17 (P17), lactation day 1 (L1), and involution day 1 (In1) mice. Images shown in large panels are small ducts (nulliparous and $\ln 7$ ) and alveoli (P17, L1, L10, In1, and In3). Images shown in insets are large ducts. TRP63, SNTRP63: arrows point to representative cells with nuclear-localized TRP63 and $\triangle$ NTRP63 expression. Closed arrowheads point to representative cells Printed in Great Britain shed into the lumen demonstrating TRP63 and $\triangle$ NTRP63 expression. KRT5: open arrowheads point to representative cells with KRT5 expression. Closed arrowhead points to representative cells shed into the lumen demonstrating KRT5 expression. ssDNA: arrows point to representative cells with myoepithelial cell localization with reactivity for ssDNA. Closed arrowheads point to representative cells shed into the lumen with reactivity for ssDNA. Large panels taken at $60 \times$ magnification, insets at $20 \times$ magnification. Scale bar $=10 \mu \mathrm{m}$

Published by Bioscientifica Ltd. 
A

Trp63 (mouse)

RT-PCR primers Real time RT-PCR primers
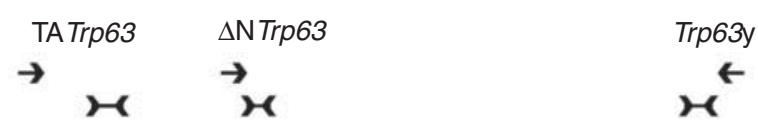

$\operatorname{Trp} 63 \alpha$

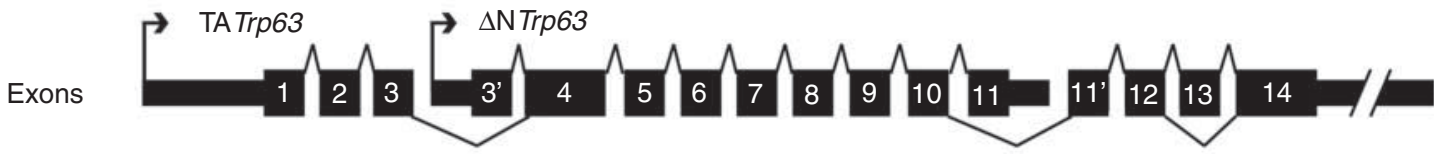

B
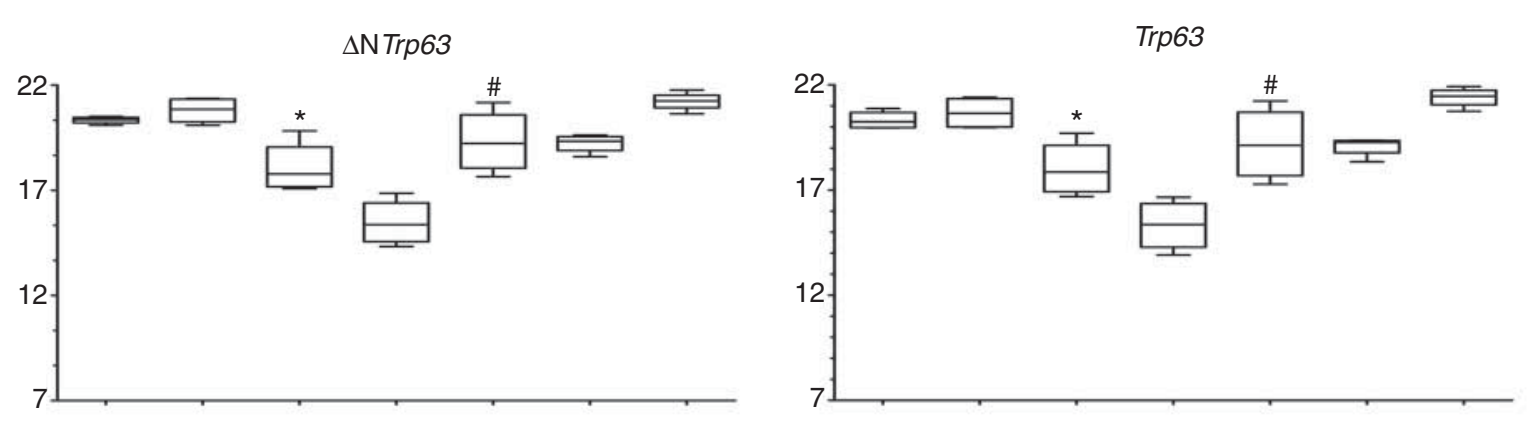

TA Trp63
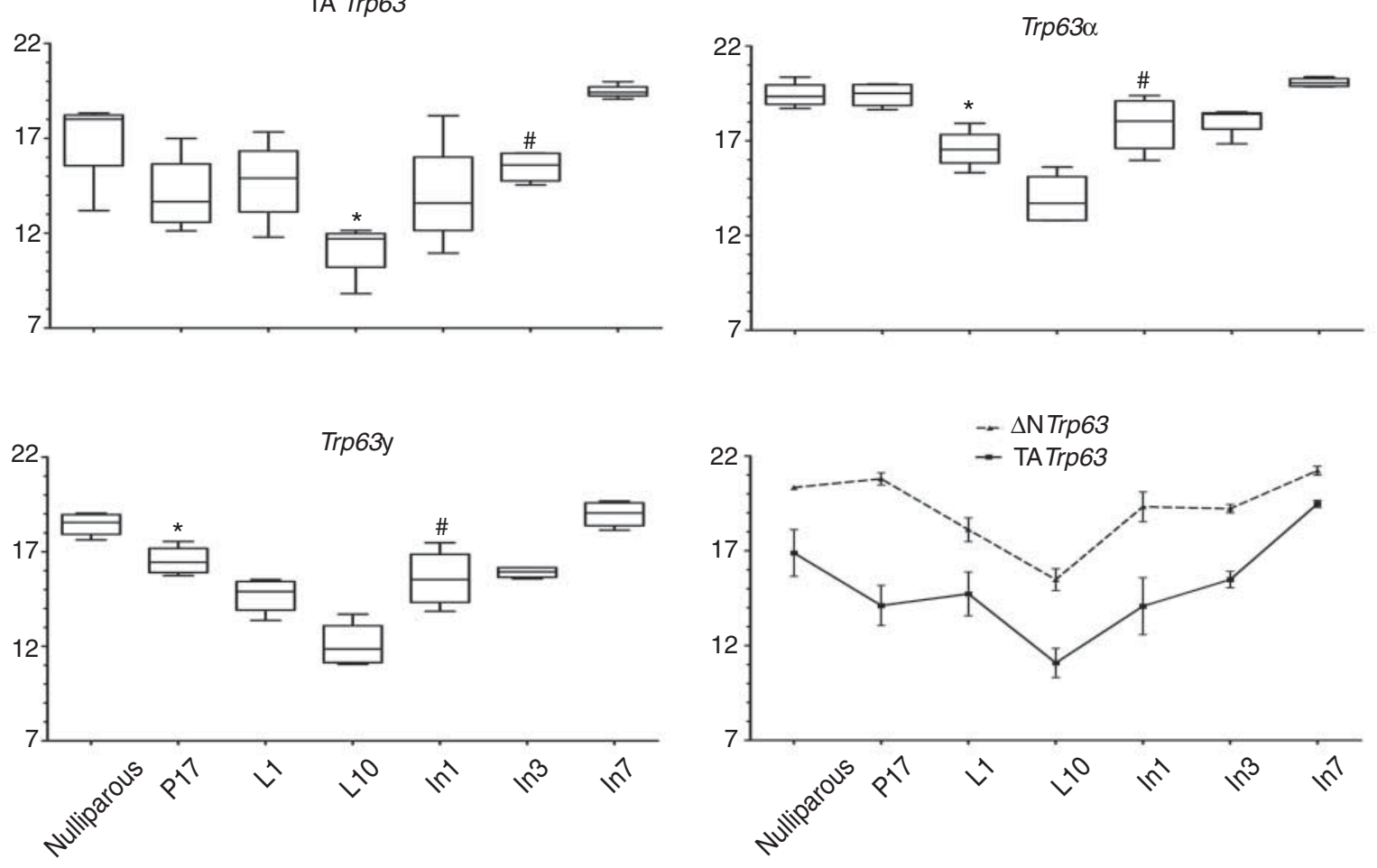

Figure 3

Changes in expression levels of Trp63 isoforms during normal mammary gland development. (A) Structure of the Trp63 gene. Splicing (lines) and alternative promoters (arrows) are indicated. Locations of primers used for real-time RT-PCR (B) and RT-PCR (Fig. 5) are illustrated. (B) Box and whisker plots demonstrating changes in relative expression levels of $\Delta N T r p 63$, total Trp63, TATrp63, Trp63 $\alpha$, and Trp63 $\gamma$ in mammary gland tissue from nulliparous, pregnancy day 17 (P17), lactation day 1 (L1), and involution

day $1(\ln 1)$ mice are shown along with line graphs comparing the relative expression levels of $\Delta \mathrm{N} T r p 63$ and TATrp63 across these reproductive stages. Expression levels of Trp63 isoforms are normalized to 18S. *The earliest stage with a statistically significant drop in expression after the nulliparous stage $(P<0.05$; Mann-Whitney $U$ test). "The earliest stage with a statistically significant increase in expression level after $L 10(P<0.05$; Mann-Whitney $U$ test).

Published by Bioscientifica Ltd. 
Trp63 $\gamma$ throughout the reproductive cycle (Fig. 3). For comparison, locations of the real-time RT-PCR primers used for detection of different spliced forms during reproduction and the RT-PCR primers used to analyze expression in cancers are both indicated herein along with exon structure, locations of the TATrp63 and $\Delta \mathrm{NTrp63}$ promoters, and 3 '-termini of the $\operatorname{Trp} 63 \alpha$ and $\operatorname{Trp} 63 \gamma$ spliced forms (Fig. 3A). It was not possible to design primers to specifically detect the Trp $63 \beta$ spliced form. The higher sensitivity of the real-time RT-PCR compared with levels of sequencing used for the RNA-seq (Fig. 1B) enabled detection of both $\Delta \mathrm{NTrp63}$ and TATrp63 spliced forms (Fig. 3B). Expression levels of both spliced forms were lowest at L10 but the kinetics of change differed. $\Delta$ NTrp63 expression was significantly lower at L1 $(P<0.05$; MannWhitney $U$ test compared with nulliparous, P17) while expression levels of TATrp63 dropped significantly only at L10 $(P<0.05$; Mann-Whitney $U$ test compared with nulliparous, P17 and L1). Likely due to the overall higher expression levels of $\Delta \mathrm{NTrp} 63$ compared with TATrp63, the significant drop in total Trp63 occurred at L1 $(P<0.05$; Mann-Whitney $U$ test compared with nulliparous, P17) as shown specifically for $\Delta \mathrm{NTrp63.} \operatorname{Trp} 63 \alpha$ forms also dropped significantly at L1 $(P<0.05$; Mann-Whitney $U$ test compared with nulliparous, P17) while Trp63r forms showed a different pattern dropping significantly at P17 $(P<0.05$; Mann-Whitney $U$ test compared with nulliparous). Expression of $\Delta \mathrm{N} \operatorname{Trp} 63$, total $\operatorname{Trp63}, \operatorname{Trp} 63 \alpha$, and Trp63 $\gamma$ all rose significantly at In 1 (all $P<0.05$; MannWhitney $U$ test compared with L1) but again the pattern of TATrp63 was unique, rising significantly only at In3. Line graphs indicated that expression of $\Delta \mathrm{NTrp} 63$ was higher than that of TATrp63 throughout reproduction. When studying gene expression during mammary gland development, interpretations of significant expression drops during lactation must include consideration of the high levels of milk protein RNAs produced at that time that could produce a dilution effect. While the highest levels of milk protein RNAs may be found at L10, milk protein RNA expression is present at L1 and In1. It is possible that lower levels of Trp63 expression were correlated with a change in cell type percentages in the mammary gland during lactation as milk-producing luminal cells were relatively more numerous than the more dispersed TRP63-expressing basal myoepithelial cells during lactation (Fig. 2). Finally, expression levels of phosphorylated STAT5, which appeared to act as a negative transcription factor (Fig. 1), are highest during lactation (Liu et al. 1996). RNA-seq data from WT nulliparous mice sampled during the estrous cycle demonstrated a doubling in Trp63 expression from 4 FPKM during estrus to 10 and 11 FPKM, respectively, during proestrus and diestrus, confirming regulated gene expression during the second type of reproductive cycle.

\section{Disruption of full-length Brca1 expression in mammary epithelium did not alter TRP63 expression patterns during mammary gland development}

Trp63 is required for establishment of mammary placodes (Yang et al. 1999). Brca1 is expressed in mammary epithelium before puberty (Marquis et al. 1995) and has been reported to positively regulate Trp63 expression (Buckley et al. 2011). To determine if loss of full-length Brca1 disrupted the pattern of TRP63 expression or myoepithelial cell differentiation, expression patterns of TRP63 and KRT5 determined by IHC were compared in mammary tissues from WT mice and Brca1-null mice with loss of full-length Brca1 targeted to MECs (Brca1 $1^{\text {f11/f11/MMTV-Cre/Trp53+/+ }}$ mice; Fig. 4). Expression patterns of TRP63 in Brca1-null mice resembled those found in WT mice, clearly detectable as nuclear-localized in basally located cells by 6 weeks of age and continuing without change at 10 weeks, 4 months, and 6 months of age. Cytoplasmically located KRT5 showed a similar pattern, also expressed at significant levels in basal myoepithelial cells by 6 weeks of age. The data indicated that full-length Brca1 does not play an essential role in regulating TRP63 expression during normal development in vivo.

\section{Expression levels of Trp63 in cancer were positively correlated with differentiation and intact Brca1}

Triple-negative mammary cancers develop in nulliparous mice with loss of full-length Brca1 targeted to MECs when one copy of germline Trp53 is disrupted (Jones et al. 2005). To assess Trp63 expression in mammary cancer cells in the absence of full-length Brca1, a set of ten triple-negative mammary carcinomas from Brca1 ${ }^{\text {f11/f11/MMTV-Cre/Trp } 53+/-}$ mice were evaluated by RT-PCR and IHC (Fig. 5). The set included non-basal and basal subtypes defined by cDNA array analyses and included eight adenocarcinomas (1, 3, and 5-10) and two spindloid cancers (2 and 4) (Herschkowitz et al. 2007). In general, $\Delta \mathrm{NTrp63}$ spliced forms were expressed at higher levels than TATrp63 spliced forms with the highest levels found in more differentiated adenocarcinomas with predominantly nuclear localization of TRP63 and $\triangle$ NTRP63 (Fig. 5). However, cytoplasmic location and additional Trp63 splice variants have also been reported in human cancers. Herein, the

Published by Bioscientifica Ltd. 

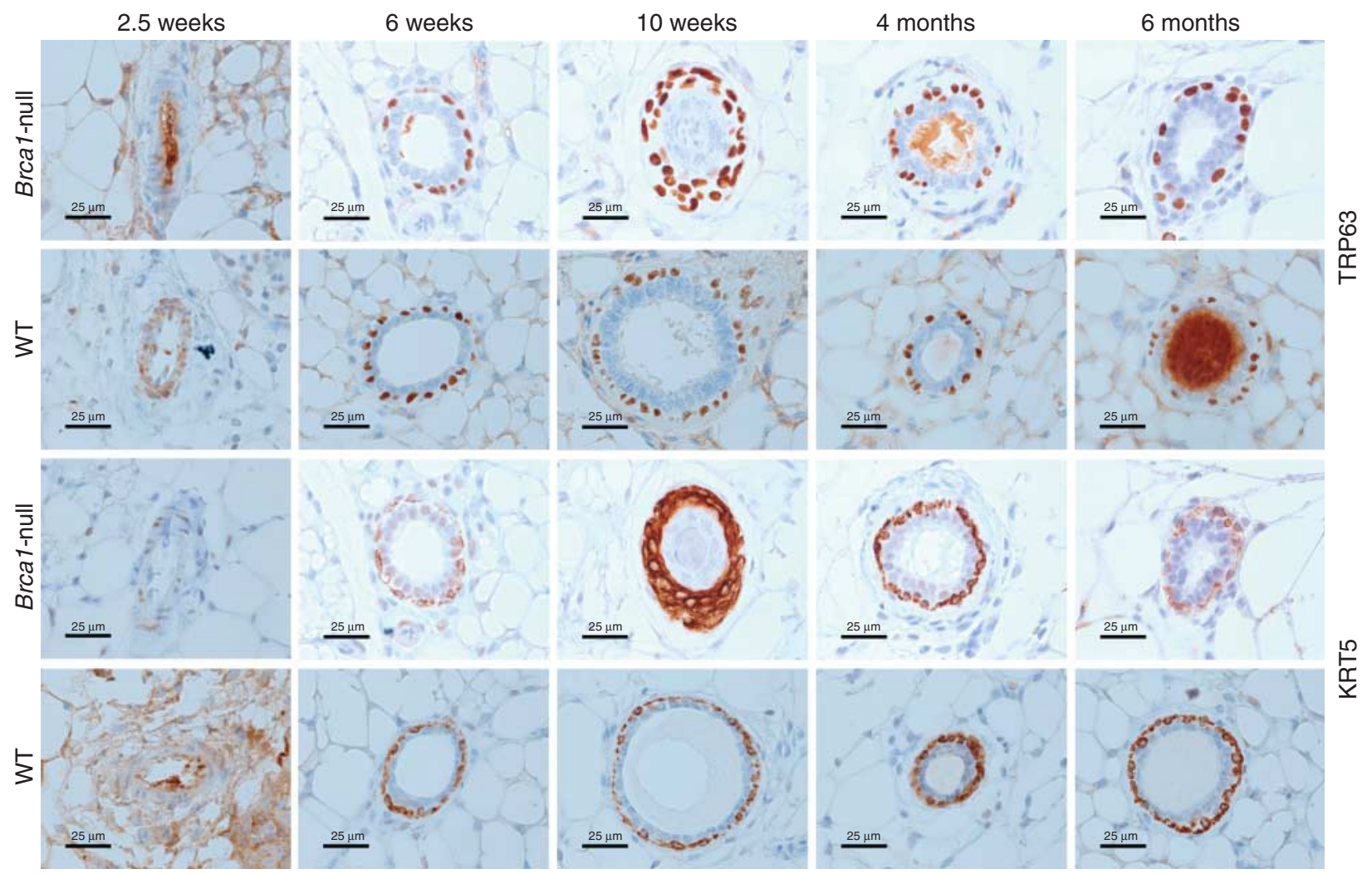

Figure 4

Immunohistochemical staining of TRP63 and KRT5 in mammary tissue from mice with and without expression of full-length Brca1. Representative images illustrating expression patterns of total TRP63 and KRT5 in

spindloid cancers showed a different pattern with undetectable RNA expression in one correlated with cytoplasmic staining (2) and relatively equal TA and $\Delta \mathrm{NTrp63 \gamma}$ expression levels in the other (4). It is possible that the cancer with cytoplasmic staining expressed an aberrant splice variant undetectable with the PCR primers used, or the staining pattern is somehow artifactual, even when appropriately controlled. Brca1 ${ }^{\text {f11/f11/MMTV-Cre/Trp } 53+}$ /- mice exhibit histological tumor heterogeneity (Nakles et al. 2013), which is the simplest explanation for disconnects in RNA and protein expression levels observed (6 and 9), but altered regulation of TRP63 translation cannot be excluded. KRT5 and ACTA2 are basal cell markers (Abd El-Rehim et al. 2004, Sarrio et al. 2008, Thike et al. 2010b). Protein expression localized to cancer cells was evaluated using IHC (Fig. 5C). Cancers classified as basal subtype demonstrating TRP63 also showed expression for KRT5 but not invariably ACTA2. KRT5 expression is not demonstrated in cancers classified as non-basal subtype with lower levels of TRP63 expression, while one of the cancers with higher levels of $\Delta \mathrm{NTrp63}$ mammary gland from nulliparous Brca1-null ( $B r c a 1^{f 11 / f 11 / M M T V-C r e / T r p 53+/+}$ ) and WT mice at ages $2.5,6$, and 10 weeks and 4 and 6 months. Images were taken at $40 \times$ magnification. Scale bar $=25 \mu \mathrm{m}$.

expression demonstrated KRT5 expression localized to cells in a ring-like pattern surrounding KRT5-negative cells. Some cancers that did not demonstrate KRT5 expression showed ACTA2 expression. Primary mammary cancer cell lines derived from triple-negative adenocarcinomas with two intact $\mathrm{BrCa} 1$ alleles $\left(\mathrm{BrCa1}^{+/+} \operatorname{Trp} 53^{+/-}\right.$) from Brca1 ${ }^{\text {WT/WT/MMTV-Cre/Trp } 53+/-/ \text { tet-op-CYP19A1/MMTV-rtTA }}$ mice, one intact Brca1 allele $\left(\mathrm{BrCa}^{+/-} \operatorname{Trp} 53^{+/-}\right)$from Brcal $^{\text {f11/WT/MMTV-Cre/Trp } 53+/-}$ mice, and two disrupted Brca1 alleles $\left(\mathrm{Brca1}^{-/-} \mathrm{Trp}^{-1 /-}\right.$ ) from Brca1 ${ }^{\text {f11/f11/MMTV-Cre/Trp } 53+/-}$ mice were used to test if loss of full-length Brca1 reduced Trp63 expression. Because Trp63 expression was higher in more differentiated cancers, the cell cultures were divided and cultured under two conditions, conditional reprogramming (Liu et al. 2012) that maintained epithelial cuboidal morphology (E) or EpiCult-B (STEMCELL Technologies), permissive for EMT, and then harvested for analysis of gene expression by RNA-seq. Significantly higher fold expression of MEC differentiation genes (Krt5, > 2000-fold; Krt8, greater than twofold; Krt1 and Krt4, >40-fold; and Krt18, greater than twofold) was

Published by Bioscientifica Ltd 
A

Non-basal carcinomas

Basal carcinomas

\begin{tabular}{|c|c|c|c|c|c|c|c|c|c|c|c|c|}
\hline & & M & 1 & 2 & 3 & 4 & 5 & 6 & 7 & 8 & 9 & 10 \\
\hline TATrp63 $\alpha$ & $2000 \mathrm{bp} \rightarrow$ & $=$ & & & . & & & & & & & \\
\hline TA Trp63及 & $1500 \mathrm{bp} \rightarrow$ & 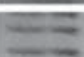 & & & & & & & & & & \\
\hline 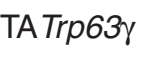 & $1500 \mathrm{bp} \rightarrow$ & $E=$ & & & $\longrightarrow$ & 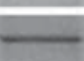 & & - & {[} & & & \\
\hline$\Delta \mathrm{N} \operatorname{Trp} 63 \alpha$ & $1750 \mathrm{bp} \rightarrow$ & $=$ & - & & 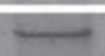 & & & $=$ & & & & \\
\hline$\Delta \mathrm{N} \operatorname{Trp63\beta }$ & $1250 \mathrm{bp} \rightarrow$ & $=$ & & & 3 & & $=$ & - & 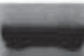 & 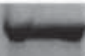 & & $=$ \\
\hline$\Delta \mathrm{N} \operatorname{Trp63\gamma }$ & $1000 \mathrm{bp} \rightarrow$ & - & $=$ & & 0 & & 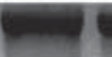 & & & & & \\
\hline Actb & $250 \mathrm{bp} \rightarrow$ & monitis & - & & 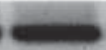 & & 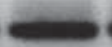 & 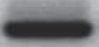 & & & & \\
\hline
\end{tabular}

\section{B

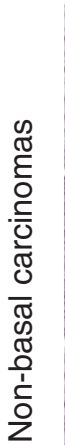

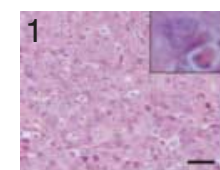

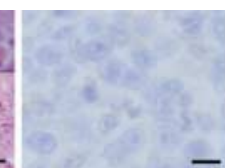

C
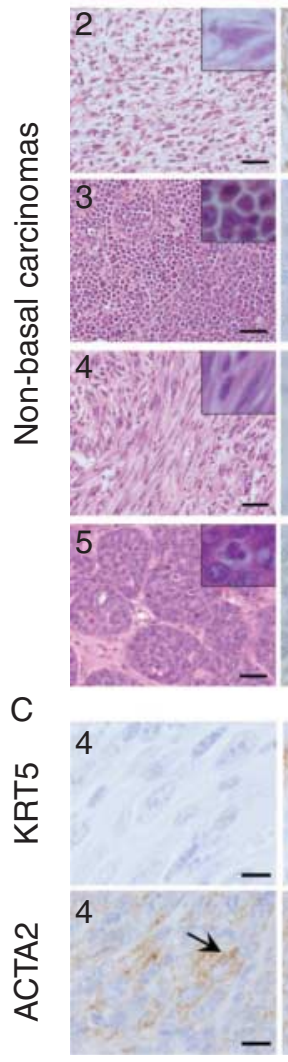$$
3
$$
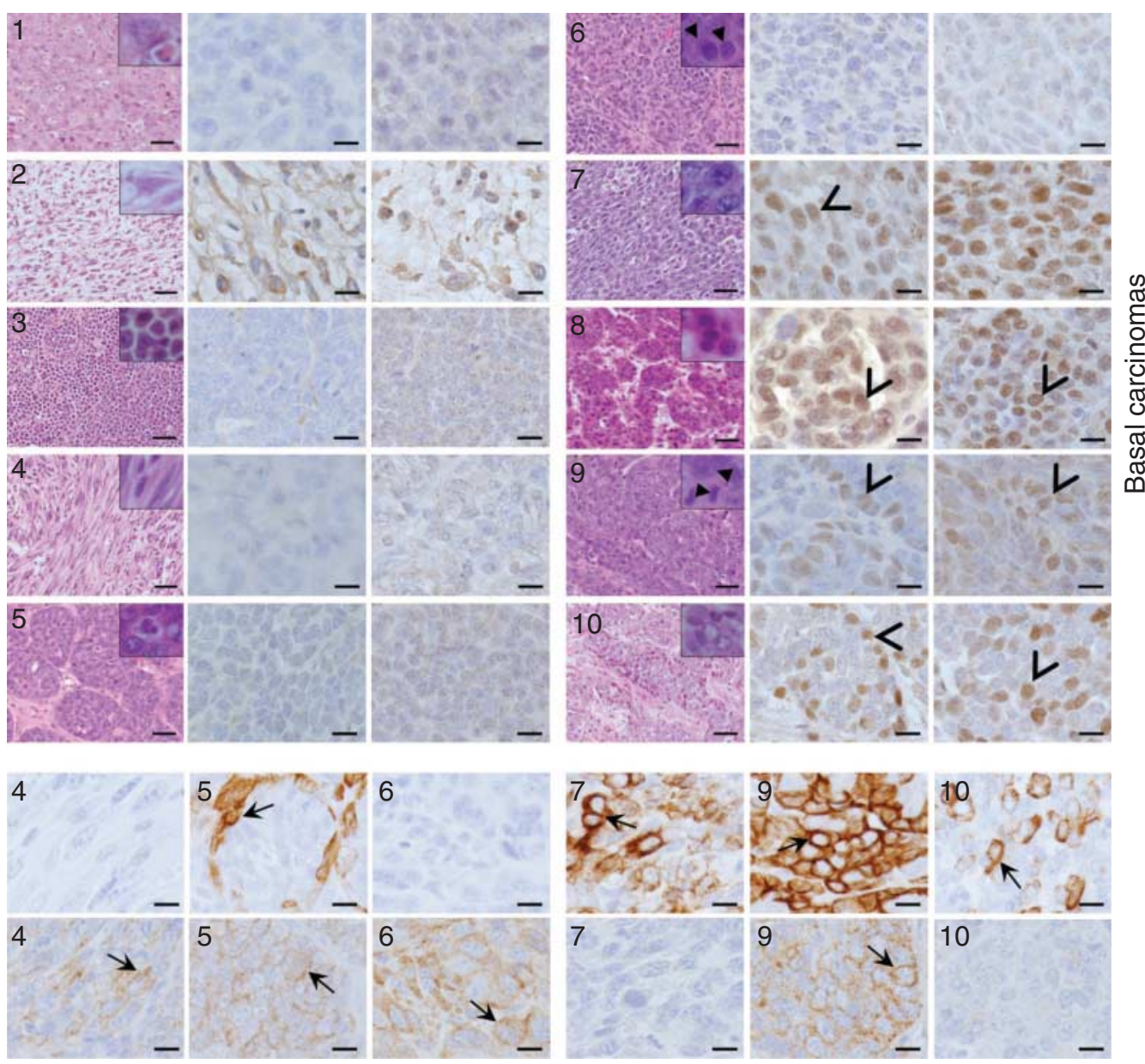

\section{Figure 5}

Expression levels of different Trp63 isoforms and basal markers in mammary carcinomas developing in Brca1 ${ }^{\text {f11/f11/MMTV-Cre/Trp } 53+/-}$ mice classified as either non-basal or basal. (A) Relative expression levels of TATrp63 $\alpha$

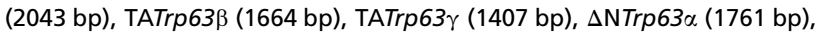
$\Delta \mathrm{N} \operatorname{Trp} 63 \beta$ (1382 bp), $\Delta \mathrm{N} \operatorname{Trp} 63 \gamma$ (1125 bp), and Actb ( $\beta$-actin control) (244 bp) in mammary carcinomas classified as non-basal (1-5) or basal (6-10) carcinomas by CDNA array analysis. Size of DNA ladder bands indicated in M (marker) lane. (B) Representative images of histology (H\&E) and expression patterns of TRP63 and $\triangle$ NTRP63 in the same non-basal (1-5) and basal (6-10) carcinomas analyzed in (A). (C) Representative images illustrating expression patterns of cytokeratin 5 (KRT5) and smooth muscle actin (ACTA2) from basal and non-basal carcinomas corresponding to lanes illustrated in (A). H\&E: large panels taken at $10 \times$ magnification, insets at $40 \times$ magnification. Scale bar $=50 \mu \mathrm{M}$. TRP63 and $\triangle$ NTRP63 panels were taken at $40 \times$ magnification. Scale bar $=10 \mu \mathrm{M}$. Open arrowheads and closed arrows indicate cells with representative immunohistochemical staining.

Published by Bioscientifica Ltd. 


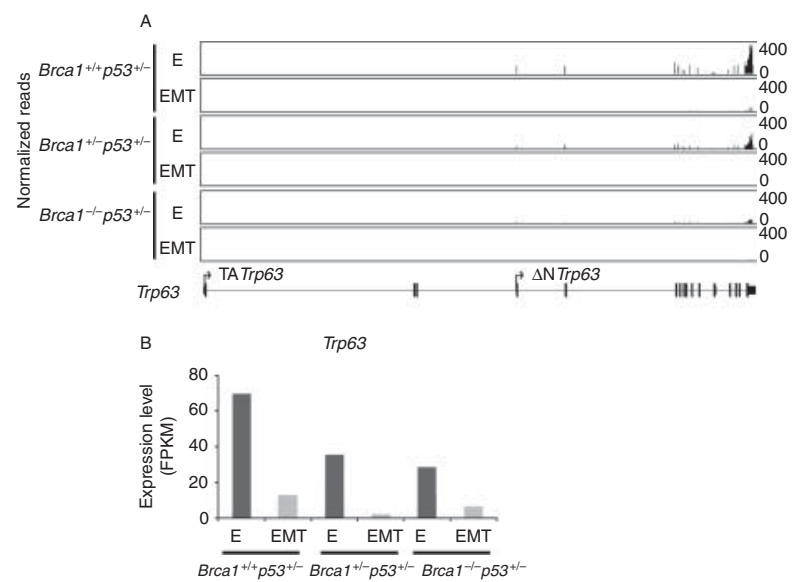

\section{Figure 6}

Expression of Trp63 isoforms in primary cell lines established from mouse mammary cancers with mutated Brca1 and Trp53 genes. (A) Normalized read coverage across the Trp63 locus viewed through the integrative genomics viewer illustrates the relative expression levels of different exons of the Trp63 gene in primary cancer cells from mice with two intact $B r c a 1$ alleles $\left(B r c a 1^{+/+}\right.$

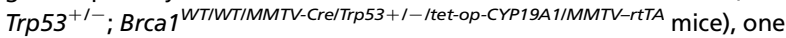

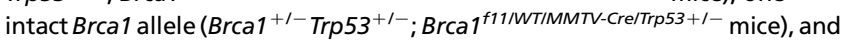
two disrupted Brca1 alleles $\left(\mathrm{BrCa}^{-1-} \mathrm{Trp53}{ }^{+/-} ; \mathrm{BrCa} 1^{\text {f11/f111/MMTV-Cre/Trp53+/- }}\right.$ mice) cultured under conditions maintaining epithelial cell differentiation (E) or permissive for epithelial mesenchymal transition (EMT). Note that exons demonstrating expression are all contained within $\Delta$ NTrp63 spliced forms. (B) Bar graphs illustrating relative fragments per kilobase of transcript per million mapped (FPKM) Trp63 reads in the primary cancer cells with varying numbers of Brca 1 alleles (A) cultured under conditions favoring epithelial cell differentiation (dark gray) or permissive for EMT (light gray).

documented in E cells when compared with EMT cells, while significantly higher fold expression of genes linked to EMT (Vim, greater than threefold; Snail1, greater than eightfold; Twist1, greater than fourfold; and Twist2, greater than sevenfold) was found in EMT cells when compared with E cells (Cuffdiff, $P<0.05$ ). The $\Delta$ NTrp63 genes were the dominant isoforms expressed across genotypes and culture conditions (Fig. 6A). Disruption of Brca1 reduced Trp63 expression levels by approximately twofold in both $\mathrm{E}$ and EMT cells (Fig. 6B). Significantly, Trp63 expression levels were at least fourfold higher in $\mathrm{E}$ cells of all genotypes (Fig. 6B). These in vitro results paralleled the in vivo expression differences in the adenocarcinomas as compared with spindloid cancers and indicate that $\operatorname{Trp} 63$ is intrinsically down-regulated during the process of EMT. Because loss of Trp63 has been linked to lower expression levels of Nrg1 (Forster et al. 2014, Yallowitz et al. 2014), expression levels were compared in the different cell lines. Expression levels were similar in E and EMT cells with one disrupted Brca1 allele (9 and 10 FPKM respectively), but reduced by greater than threefold in EMT (4 FPKM) as compared with E (13 FPKM) cells with two disrupted Brca1 alleles (Cuffdiff; $P<0.05$ ).

\section{Discussion}

These studies, for the first time, provide insight into the chromatin landscape of the Trp63 locus in mouse mammary epithelium and provide genetic evidence that STAT5 is a negative regulator of this gene. Two classes of Trp63 isoforms had been reported, the long TA and short $\Delta \mathrm{N}$ forms, which are derived from transcripts originating from the distal and proximal promoters respectively. Based on ChIP-seq data, H3K4me2 and H3K4me3 activating chromatin marks are associated almost exclusively with the proximal promoter encoding the $\Delta \mathrm{NTrp} 63$ spliced forms portending the significantly higher levels of $\Delta \mathrm{NTrp63}$ as compared with TATrp63 documented by RNA-seq and RT-PCR across normal development and many of the cancers. $\triangle$ NTRP63 isoforms are shown to act as survival factors in normal and cancer cells of epithelial origin (Mills et al. 1999, Lee et al. 2006, Rocco et al. 2006, Dugani et al. 2009) compatible with a role for $\triangle \mathrm{NTRP} 63$ in promoting cancer cell survival in cancers that express it. However, it is clear both in human breast cancers (Laakso et al. 2005, Jumppanen et al. 2007, Moriya et al. 2009, Thike et al. 2010b, Lehmann et al. 2011, Shao et al. 2011, Furuya et al. 2012, Yao \& Chen 2012, Masuda et al. 2013, Shekhar et al. 2013) and in mammary cancers that develop

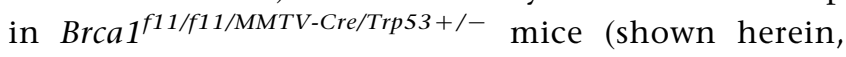
Nakles et al. 2013) that not all cancers express $\triangle$ NTRP63, indicating that it is not absolutely required for cancer development.

Breast cancer is a heterogeneous disease and the BrCa1 $1^{\text {f11/f11/MMTV-Cre/Trp53+/- }}$ mice develop a spectrum of triple-negative breast cancer subtypes (Herschkowitz et al. 2007). Percentages of cancers showing nuclear-localized TRP63 reported herein parallel previously reported results with $\sim 50 \%$ of the cancers showing strong protein expression on IHC, which is associated with concomitant KRT5 expression (Nakles et al. 2013) but is more variably accompanied by ACTA2 expression. This expression pattern is different from normal mature myoepithelial cells, where all three of these markers are expressed synchronously, but parallels results from human breast cancers, where discordant expression is also found (Laakso et al. 2005, Jumppanen et al. 2007). It has been recently reported that TRP63 detected in cancers represents $\triangle$ NTRP63 isoform expression predominantly, confirming that the BrCa1 ${ }^{\text {f11/f11/MMTV-Cre/Trp53+/- }}$ mouse model has the same pattern of TRP63 and $\triangle$ NTRP63 isoform expression described in human breast cancers (Su et al. 2013). This is the form most closely linked to MEC survival (Yallowitz et al. 2014), compatible with it mediating a role in cancer

Published by Bioscientifica Ltd 
cell survival in this model. TRP63 also has been linked to maintenance of PI-MECs that in turn can have an impact on the extent of pregnancy-induced ErbB2 cancer development (Yallowitz et al. 2014). Herein, cancers were studied from nulliparous Brca1 $111 / f 11 / M M T V-C r e / T r p 53+/-$ mice but it remains possible that TRP63 contributed to survival of cancer progenitor cells. The RNA studies provide novel information on expression of spliced forms of Trp63 in cancers, illustrate that they are not all identical in cancers (even developing within one genetically engineered mouse model), and establish the higher sensitivity of RNA for detection of gene activity. The spectrum of Trp63 expression in the different histological cancer types developing in this model and the fact that cancers develop in nulliparous mice at high frequency suggest that it would be a suitable preclinical model for the next set of investigations exploring the impact of Trp63 deletion on cancer pathophysiology and therapeutic outcome. Nrg1 is expressed in the primary cell lines developed from the cancers with one and two disrupted Brca1 alleles, providing linked in vivo and in vitro models for study of a possible role for Nrg1 in cancer development linked to loss of Brca1 function. A similar approach to develop cell lines from human breast cancers with mutated Brca1 alleles could be used to develop parallel human models (Liu et al. 2012). In both humans with mutated BRCA1 and mice with disrupted Brca1 alleles, accumulation of altered luminal progenitor cells is suggested to represent the population from which eventual cancer cells are derived (Lim et al. 2009, Smart et al. 2011).

Here, STAT5 emerged as a negative regulator of Trp63 with genetic reduction of STAT5 levels resulting in increased Trp63 levels, a new finding. This negative regulation is consistent with the cellular localization of TRP63 to basal myoepithelial cells, while STAT5 is primarily expressed in mammary luminal cells. This expands upon the interplay between TRP63 and activated STAT5 in mammary epithelium mediated by Nrg1 (Forster et al. 2014). TRP63 expression in mammary myoepithelial cells is required for activation of STAT5 in luminal cells, but then STAT5 might act to repress Trp63 expression in these luminal cells. Similar to other studies, these results demonstrate TRP63 expression throughout all postpubertal mammary gland development phases with $\Delta$ NTRP63 expression predominating (Parsa et al. 1999, Forster et al. 2014, Yallowitz et al. 2014) but extend them by documenting the expression patterns of all six different isoforms and showing that loss of Brca1 does not alter the basic pattern of nuclear localization in myoepithelial cells.
PGR binding was also localized to $\Delta$ NTrp63 promoter region and interactions between STAT5 and PGR have been reported. PGR is also expressed primarily in luminal mammary cells and may also be a negative regulator of $\Delta \mathrm{NTrp63}$, but this hypothesis needs to be directly tested in vivo. Experiments confirmed that BRCA1 is not essential for Trp63 expression but, in agreement with the previous literature, demonstrated that increased Trp63 expression was associated with higher levels of full-length Brca1. Expression of TRP63 and $\triangle$ NTRP63 in basal myoepithelial cells first appears during normal mammary gland pubertal differentiation. This study demonstrated that expression of Trp63 is also linked positively to differentiation in mammary cancers, both in vivo and in vitro. Significantly, prevalence of TRP63 in cancers developing in

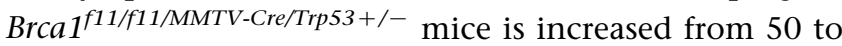
$92 \%$ by treatment with efatutazone, a differentiating agent that is a ligand for peroxisome proliferator-activated receptor gamma $(\operatorname{PPAR} \gamma)$, and demonstrated a lower prevalence of TRP63 expression in spindloid cancers as compared with more differentiated cancer subtypes (Nakles et al. 2013). Herein, we showed that transcriptional regulatory mechanisms activated during EMT (Lindsay et al. 2011) include Trp63 down-regulation.

It is challenging to assign RNA expression patterns to a specific cell type when working with whole tissue. Experiments herein demonstrated that TRP63 and $\Delta$ NTRP63 remained nuclear-localized to basal myoepithelial cells across different stages of reproductive development. RNA expression levels can be measured by a variety of methods. Herein, we showed that the RT-PCR technology used was more sensitive than the conditions employed for RNA-seq (40-100 million reads) for detection of the TATrp63 isoforms. The lower levels of Trp63 expression found herein during lactation as compared with nulliparous mice may be secondary to the lower percentage of myoepithelial cells as compared with luminal cells at that time point, as expression of Trp63 in isolated luminal cells is very low and not significantly changed in isolated basal cells between those two time points (Forster et al. 2014). Expression does consistently appear to be increased with differentiation when changes in cell population types is not a factor as observed with the increase during the estrous cycle and with differentiation in cell culture as shown herein.

In conclusion, this study contributes new information on the regulation of Trp63, implicating STAT5 and defining the role of BRCA1 and demonstrating the impact of differentiation. RNA isoform and protein expression patterns across normal mammary gland development,

Published by Bioscientifica Ltd. 
including reproductive cycles, were explicitly defined, illustrating a predominant role for the $\triangle$ NTRP63 isoforms. A validated genetically engineered mouse model suitable for further studies investigating the impact of TRP63 on mammary disease and therapy was presented.

\section{Declaration of interest}

S Assefnia, K Kang, S Groeneveld, D Yamaji, S Dabydeen, A Alamri, L Hennighausen and P A Furth declare that there is no conflict of interest that could be perceived as prejudicing the impartiality of the research reported. Georgetown University has submitted a patent application for the cell reprogramming technology described, on which $X$ Liu is an inventor. The intellectual property is under an exclusive license to Propagenix in which Georgetown University has a founding equity interest.

\section{Funding}

This research was supported in part by NIH NCI RO1 CA112176 (P A Furth), DOD W81XWH-07-1-058 (P A Furth), NIH IG20RR025828 (Rodent Barrier Facility Equipment), NIH 1R21CA180524 (X Liu), Cherry Blossom Breast Cancer Foundation Grant (X Liu), and NIH NCI 5P30CA051008 (Histology and Tissue, Genomics and Epigenomics, and Animal Shared Resources). Part of this research was funded by the Intramural Research Program of NIDDK/NIH.

\section{Author contribution statement}

$S$ Assefnia and $\mathrm{K}$ Kang contributed equally to this work, and with L Hennighausen and P A Furth designed, performed, and analyzed experiments, prepared figures, and wrote the manuscript. S Groeneveld, A Alamri, and X Liu cultured primary cells. S Dabydeen prepared RNA-seq libraries.

\section{Acknowledgements}

We thank M Carla Cabrera and Sarah L Millman for acquisition of immunohistochemistry images (Fig. 4).

\section{References}

Abd El-Rehim DM, Pinder SE, Paish CE, Bell J, Blamey RW, Robertson JF, Nicholson RI \& Ellis IO 2004 Expression of luminal and basal cytokeratins in human breast carcinoma. Journal of Pathology $\mathbf{2 0 3}$ 661-671. (doi:10.1002/path.1559)

Bankfalvi A, Ludwig A, De-Hesselle B, Buerger H, Buchwalow IB \& Boecker W 2004 Different proliferative activity of the glandular and myoepithelial lineages in benign proliferative and early malignant breast diseases. Modern Pathology 17 1051-1061. (doi:10.1038/ modpathol.3800082)

Barton CE, Johnson KN, Mays DM, Boehnke K, Shyr Y, Boukamp P \& Pietenpol JA 2010 Novel p63 target genes involved in paracrine signaling and keratinocyte differentiation. Cell Death \& Disease 1 e74. (doi:10.1038/cddis.2010.49)

Buckley NE \& Mullan PB 2012 BRCA1 - conductor of the breast stem cell orchestra: the role of BRCA1 in mammary gland development and identification of cell of origin of BRCA1 mutant breast cancer. Stem Cell Reviews 8 982-983. (doi:10.1007/s12015-012-9354-y)

Buckley NE, Conlon SJ, Jirstrom K, Kay EW, Crawford NT, O'Grady A, Sheehan K, Mc Dade SS, Wang CW, McCance DJ et al. 2011 The $\Delta$ Np63

http://erc.endocrinology-journals.org DOI: 10.1530/ERC-14-0032
(C) 2014 Society for Endocrinology Printed in Great Britain proteins are key allies of BRCA1 in the prevention of basal-like breast cancer. Cancer Research 71 1933-1944. (doi:10.1158/0008-5472.CAN10-2717)

Celardo I, Grespi F, Antonov A, Bernassola F, Garabadgiu AV, Melino G \& Amelio I 2013 Caspase-1 is a novel target of p63 in tumor suppression. Cell Death \& Disease 4 e645. (doi:10.1038/cddis.2013.175)

Cheung KJ, Gabrielson E, Werb Z \& Ewald AJ 2013 Collective invasion in breast cancer requires a conserved basal epithelial program. Cell $\mathbf{1 5 5}$ 1639-1651. (doi:10.1016/j.cell.2013.11.029)

Chu WK, Dai PM, Li HL \& Chen JK 2008 Transcriptional activity of the $\Delta$ Np63 promoter is regulated by STAT3. Journal of Biological Chemistry 283 7328-7337. (doi:10.1074/jbc.M800183200)

Cui Y, Riedlinger G, Miyoshi K, Tang W, Li C, Deng CX, Robinson GW \& Hennighausen L 2004 Inactivation of Stat5 in mouse mammary epithelium during pregnancy reveals distinct functions in cell proliferation, survival, and differentiation. Molecular and Cellular Biology 24 8037-8047. (doi:10.1128/MCB.24.18.8037-8047.2004)

Dohn M, Zhang S \& Chen X 2001 p63 $\alpha$ and $\Delta$ Np63 $\alpha$ can induce cell cycle arrest and apoptosis and differentially regulate p53 target genes. Oncogene 20 3193-3205. (doi:10.1038/sj.onc.1204427)

Dugani CB, Paquin A, Fujitani M, Kaplan DR \& Miller FD 2009 p63 antagonizes p53 to promote the survival of embryonic neural precursor cells. Journal of Neuroscience 29 6710-6721. (doi:10.1523/JNEUROSCI. 5878-08.2009)

Fata JE, Chaudhary V \& Khokha R 2001 Cellular turnover in the mammary gland is correlated with systemic levels of progesterone and not $17 \beta$ estradiol during the estrous cycle. Biology of Reproduction 65 680-688. (doi:10.1095/biolreprod65.3.680)

Forster N, Saladi SV, van Bragt M, Sfondouris ME, Jones FE, Li Z \& Ellisen LW 2014 Basal cell signaling by p63 controls luminal progenitor function and lactation via NRG1. Developmental Cell 28 147-160. (doi:10.1016/j.devcel.2013.11.019)

Frankfurt OS 2004 Immunoassay for single-stranded DNA in apoptotic cells. Methods in Molecular Biology 282 85-101.

Furuya C, Kawano H, Yamanouchi T, Oga A, Ueda J \& Takahashi M 2012 Combined evaluation of CK5/6, ER, p63, and MUC3 for distinguishing breast intraductal papilloma from ductal carcinoma in situ. Pathology International 62 381-390. (doi:10.1111/j.1440-1827.2012.02811.x)

Heinz S, Benner C, Spann N, Bertolino E, Lin YC, Laslo P, Cheng JX, Murre C, Singh H \& Glass CK 2010 Simple combinations of lineagedetermining transcription factors prime cis-regulatory elements required for macrophage and B cell identities. Molecular Cell $\mathbf{3 8}$ 576-589. (doi:10.1016/j.molcel.2010.05.004)

Herschkowitz JI, Simin K, Weigman VJ, Mikaelian I, Usary J, Hu Z, Rasmussen KE, Jones LP, Assefnia S, Chandrasekharan S et al. 2007 Identification of conserved gene expression features between murine mammary carcinoma models and human breast tumors. Genome Biology 8 R76. (doi:10.1186/gb-2007-8-5-r76)

Jones LP, Li M, Halama ED, Ma Y, Lubet R, Grubbs CJ, Deng CX, Rosen EM $\&$ Furth PA 2005 Promotion of mammary cancer development by tamoxifen in a mouse model of Brca1-mutation-related breast cancer. Oncogene 24 3554-3562. (doi:10.1038/sj.onc.1208426)

Jumppanen M, Gruvberger-Saal S, Kauraniemi P, Tanner M, Bendahl PO, Lundin M, Krogh M, Kataja P, Borg A, Ferno M et al. 2007 Basal-like phenotype is not associated with patient survival in estrogen-receptornegative breast cancers. Breast Cancer Research 9 R16. (doi:10.1186/ bcr1649)

Kang K, Yamaji D, Yoo KH, Robinson GW \& Hennighausen L 2014 Mammary-specific gene activation is defined by progressive recruitment of STAT5 during pregnancy and the establishment of H3K4me3 marks. Molecular and Cellular Biology 34 464-473. (doi:10.1128/MCB.00988-13)

Kim D, Pertea G, Trapnell C, Pimentel H, Kelley R \& Salzberg SL 2013 TopHat2: accurate alignment of transcriptomes in the presence of insertions, deletions and gene fusions. Genome Biology 14 R36. (doi:10.1186/gb-2013-14-4-r36) 
Koster MI, Dai D, Marinari B, Sano Y, Costanzo A, Karin M \& Roop DR 2007 p63 induces key target genes required for epidermal morphogenesis. PNAS 104 3255-3260. (doi:10.1073/pnas.0611376104)

Kurita T, Cunha GR, Robboy SJ, Mills AA \& Medina RT 2005 Differential expression of p63 isoforms in female reproductive organs. Mechanisms of Development 122 1043-1055. (doi:10.1016/j.mod.2005.04.008)

Laakso M, Loman N, Borg A \& Isola J 2005 Cytokeratin 5/14-positive breast cancer: true basal phenotype confined to BRCA1 tumors. Modern Pathology 18 1321-1328. (doi:10.1038/modpathol.3800456)

Lain AR, Creighton CJ \& Conneely OM 2013 Research resource: progesterone receptor targetome underlying mammary gland branching morphogenesis. Molecular Endocrinology 27 1743-1761. (doi:10.1210/me.2013-1144)

Lee HO, Lee JH, Choi E, Seol JY, Yun Y \& Lee H 2006 A dominant negative form of p63 inhibits apoptosis in a p53-independent manner. Biochemical and Biophysical Research Communications 344 166-172. (doi:10.1016/j.bbrc.2006.03.128)

Lehmann BD, Bauer JA, Chen X, Sanders ME, Chakravarthy AB, Shyr Y \& Pietenpol JA 2011 Identification of human triple-negative breast cancer subtypes and preclinical models for selection of targeted therapies. Journal of Clinical Investigation 121 2750-2767. (doi:10.1172/ JCI45014)

Li M, Hu J, Heermeier K, Hennighausen L \& Furth PA 1996 Apoptosis and remodeling of mammary gland tissue during involution proceeds through p53-independent pathways. Cell Growth \& Differentiation 7 $13-20$.

Li M, Liu X, Robinson G, Bar-Peled U, Wagner KU, Young WS, Hennighausen L \& Furth PA 1997 Mammary-derived signals activate programmed cell death during the first stage of mammary gland involution. PNAS 94 3425-3430. (doi:10.1073/pnas.94.7.3425)

Liefer KM, Koster MI, Wang XJ, Yang A, McKeon F \& Roop DR 2000 Downregulation of p63 is required for epidermal UV-B-induced apoptosis. Cancer Research 60 4016-4020.

Lim E, Vaillant F, Wu D, Forrest NC, Pal B, Hart AH, Asselin-Labat ML, Gyorki DE, Ward T, Partanen A et al. 2009 Aberrant luminal progenitors as the candidate target population for basal tumor development in BRCA1 mutation carriers. Nature Medicine 15 907-913. (doi:10.1038/ nm.2000)

Lindsay J, McDade SS, Pickard A, McCloskey KD \& McCance DJ 2011 Role of $\Delta \mathrm{Np} 63 \gamma$ in epithelial to mesenchymal transition. Journal of Biological Chemistry 286 3915-3924. (doi:10.1074/jbc.M110.162511)

Liu X, Robinson GW \& Hennighausen L 1996 Activation of Stat5a and Stat $5 \mathrm{~b}$ by tyrosine phosphorylation is tightly linked to mammary gland differentiation. Molecular Endocrinology 10 1496-1506.

Liu X, Robinson GW, Wagner KU, Garrett L, Wynshaw-Boris A \& Hennighausen L 1997 Stat5a is mandatory for adult mammary gland development and lactogenesis. Genes and Development 11 179-186. (doi:10.1101/gad.11.2.179)

Liu H, Fan Q, Zhang Z, Li X, Yu H \& Meng F 2008 Basal-HER2 phenotype shows poorer survival than basal-like phenotype in hormone receptornegative invasive breast cancers. Human Pathology 39 167-174. (doi:10.1016/j.humpath.2007.06.012)

Liu X, Ory V, Chapman S, Yuan H, Albanese C, Kallakury B, Timofeeva OA, Nealon C, Dakic A, Simic V et al. 2012 ROCK inhibitor and feeder cells induce the conditional reprogramming of epithelial cells. American Journal of Pathology 180 599-607. (doi:10.1016/j.ajpath.2011.10.036)

Marquis ST, Rajan JV, Wynshaw-Boris A, Xu J, Yin GY, Abel KJ, Weber BL \& Chodosh LA 1995 The developmental pattern of Brca1 expression implies a role in differentiation of the breast and other tissues. Nature Genetics 11 17-26. (doi:10.1038/ng0995-17)

Masuda H, Baggerly KA, Wang Y, Zhang Y, Gonzalez-Angulo AM, MericBernstam F, Valero V, Lehmann BD, Pietenpol JA, Hortobagyi GN et al. 2013 Differential response to neoadjuvant chemotherapy among 7 triple-negative breast cancer molecular subtypes. Clinical Cancer Research 19 5533-5540. (doi:10.1158/1078-0432.CCR-13-0799)
Mattiske S, Ho K, Noll JE, Neilsen PM, Callen DF \& Suetani RJ 2013 TAp63 regulates oncogenic miR-155 to mediate migration and tumour growth. Oncotarget 4 1894-1903.

Mills AA, Zheng B, Wang XJ, Vogel H, Roop DR \& Bradley A 1999 p63 is a p53 homologue required for limb and epidermal morphogenesis. Nature 398 708-713. (doi:10.1038/19531)

Montagner M, Enzo E, Forcato M, Zanconato F, Parenti A, Rampazzo E, Basso G, Leo G, Rosato A, Bicciato S et al. 2012 SHARP1 suppresses breast cancer metastasis by promoting degradation of hypoxiainducible factors. Nature $\mathbf{4 8 7}$ 380-384. (doi:10.1038/nature11207)

Moriya T, Kozuka Y, Kanomata N, Tse GM \& Tan PH 2009 The role of immunohistochemistry in the differential diagnosis of breast lesions. Pathology 41 68-76. (doi:10.1080/00313020802563544)

Murray-Zmijewski F, Lane DP \& Bourdon JC 2006 p53/p63/p73 isoforms: an orchestra of isoforms to harmonise cell differentiation and response to stress. Cell Death and Differentiation 13 962-972. (doi:10.1038/sj.cdd. 4401914)

Nakles RE, Kallakury BV \& Furth PA 2013 The PPAR $\gamma$ agonist efatutazone increases the spectrum of well-differentiated mammary cancer subtypes initiated by loss of full-length BRCA1 in association with TP53 haploinsufficiency. American Journal of Pathology 182 1976-1985. (doi:10.1016/j.ajpath.2013.02.006)

Nylander K, Vojtesek B, Nenutil R, Lindgren B, Roos G, Zhanxiang W, Sjostrom B, Dahlqvist A \& Coates PJ 2002 Differential expression of p63 isoforms in normal tissues and neoplastic cells. Journal of Pathology 198 417-427. (doi:10.1002/path.1231)

Oh JE, Kim RH, Shin KH, Park NH \& Kang MK 2011 DNp63 protein triggers epithelial-mesenchymal transition and confers stem cell properties in normal human keratinocytes. Journal of Biological Chemistry $\mathbf{2 8 6}$ 38757-38767. (doi:10.1074/jbc.M111.244939)

Parsa R, Yang A, McKeon F \& Green H 1999 Association of p63 with proliferative potential in normal and neoplastic human keratinocytes. Journal of Investigative Dermatology 113 1099-1105. (doi:10.1046/j. 1523-1747.1999.00780.x)

Pellegrini G, Dellambra E, Golisano O, Martinelli E, Fantozzi I, Bondanza S, Ponzin D, McKeon F \& De Luca M 2001 p63 identifies keratinocyte stem cells. PNAS 98 3156-3161. (doi:10.1073/pnas.061032098)

Piccolo S, Enzo E \& Montagner M 2013 p63, Sharp1, and HIFs: master regulators of metastasis in triple-negative breast cancer. Cancer Research 73 4978-4981. (doi:10.1158/0008-5472.CAN-13-0962)

Pietsch EC, Sykes SM, McMahon SB \& Murphy ME 2008 The p53 family and programmed cell death. Oncogene 27 6507-6521. (doi:10.1038/onc. 2008.315)

Pignon JC, Grisanzio C, Geng Y, Song J, Shivdasani RA \& Signoretti S 2013 p63-expressing cells are the stem cells of developing prostate, bladder, and colorectal epithelia. PNAS 110 8105-8110. (doi:10.1073/pnas. $1221216110)$

Ribeiro-Silva A, Ramalho LN, Garcia SB, Brandao DF, Chahud F \& Zucoloto S 2005 p63 correlates with both BRCA1 and cytokeratin 5 in invasive breast carcinomas: further evidence for the pathogenesis of the basal phenotype of breast cancer. Histopathology 47 458-466. (doi:10.1111/j.1365-2559.2005.02249.x)

Rijnkels M, Freeman-Zadrowski C, Hernandez J, Potluri V, Wang L, Li W \& Lemay DG 2013 Epigenetic modifications unlock the milk protein gene loci during mouse mammary gland development and differentiation. PLOS ONE 8 e53270. (doi:10.1371/journal.pone.0053270)

Robinson JT, Thorvaldsdottir H, Winckler W, Guttman M, Lander ES, Getz G \& Mesirov JP 2011 Integrative genomics viewer. Nature Biotechnology 29 24-26. (doi:10.1038/nbt.1754)

Rocco JW, Leong CO, Kuperwasser N, DeYoung MP \& Ellisen LW 2006 p63 mediates survival in squamous cell carcinoma by suppression of p73-dependent apoptosis. Cancer Cell 9 45-56. (doi:10.1016/j.ccr. 2005.12.013)

Sarrio D, Rodriguez-Pinilla SM, Hardisson D, Cano A, Moreno-Bueno G \& Palacios J 2008 Epithelial-mesenchymal transition in breast cancer http://erc.endocrinology-journals.org DOI: 10.1530/ERC-14-0032
(C) 2014 Society for Endocrinology Printed in Great Britain 
relates to the basal-like phenotype. Cancer Research 68 989-997. (doi:10.1158/0008-5472.CAN-07-2017)

Sbisa E, Mastropasqua G, Lefkimmiatis K, Caratozzolo MF, D’Erchia AM \& Tullo A 2006 Connecting p63 to cellular proliferation: the example of the adenosine deaminase target gene. Cell Cycle 5 205-212. (doi:10.4161/cc.5.2.2361)

Schorr K \& Furth PA 2000 Induction of bcl-xL expression in mammary epithelial cells is glucocorticoid-dependent but not signal transducer and activator of transcription 5-dependent. Cancer Research 60 5950-5953.

Schorr K, Li M, Bar-Peled U, Lewis A, Heredia A, Lewis B, Knudson CM, Korsmeyer SJ, Jager R, Weiher $\mathrm{H}$ et al. 1999 Gain of Bcl-2 is more potent than bax loss in regulating mammary epithelial cell survival in vivo. Cancer Research 59 2541-2545.

Senoo M, Manis JP, Alt FW \& McKeon F 2004 p63 and p73 are not required for the development and p53-dependent apoptosis of $\mathrm{T}$ cells. Cancer Cell 6 85-89. (doi:10.1016/j.ccr.2004.06.005)

Senoo M, Pinto F, Crum CP \& McKeon F 2007 p63 is essential for the proliferative potential of stem cells in stratified epithelia. Cell $\mathbf{1 2 9}$ 523-536. (doi:10.1016/j.cell.2007.02.045)

Shao MM, Liu J, Vong JS, Niu Y, Germin B, Tang P, Chan AW, Lui PC, Law BK, Tan PH et al. 2011 A subset of breast cancer predisposes to brain metastasis. Medical Molecular Morphology 44 15-20. (doi:10.1007/ s00795-010-0495-2)

Shekhar MP, Kato I, Nangia-Makker P \& Tait L 2013 Comedo-DCIS is a precursor lesion for basal-like breast carcinoma: identification of a novel p63/Her2/neu expressing subgroup. Oncotarget 4 231-241.

Smart CE, Wronski A, French JD, Edwards SL, Asselin-Labat ML, Waddell N, Peters K, Brewster BL, Brooks K, Simpson K et al. 2011 Analysis of Brca1deficient mouse mammary glands reveals reciprocal regulation of Brca1 and c-kit. Oncogene 30 1597-1607. (doi:10.1038/onc.2010.538)

Su X, Chakravarti D \& Flores ER 2013 p63 steps into the limelight: crucial roles in the suppression of tumorigenesis and metastasis. Nature Reviews. Cancer 13 136-143. (doi:10.1038/nrc3446)

Thike AA, Cheok PY, Jara-Lazaro AR, Tan B, Tan P \& Tan PH 2010a Triple-negative breast cancer: clinicopathological characteristics and relationship with basal-like breast cancer. Modern Pathology 23 123-133. (doi:10.1038/modpathol.2009.145)

Thike AA, Iqbal J, Cheok PY, Chong AP, Tse GM, Tan B, Tan P, Wong NS \& Tan PH $2010 b$ Triple negative breast cancer: outcome correlation with immunohistochemical detection of basal markers. American Journal of Surgical Pathology 34 956-964. (doi:10.1097/PAS.0b013e3181e02f45)

Thike AA, Iqbal J, Cheok PY, Tse GM \& Tan PH 2013 Ductal carcinoma in situ associated with triple negative invasive breast cancer: evidence for a precursor-product relationship. Journal of Clinical Pathology $\mathbf{6 6}$ 665-670. (doi:10.1136/jclinpath-2012-201428)
Tran MN, Choi W, Wszolek MF, Navai N, Lee IL, Nitti G, Wen S, Flores ER, Siefker-Radtke A, Czerniak B et al. 2013 The p63 protein isoform Np63 inhibits epithelial-mesenchymal transition in human bladder cancer cells: role of MIR-205. Journal of Biological Chemistry 288 3275-3288. (doi:10.1074/jbc.M112.408104)

Trapnell C, Williams BA, Pertea G, Mortazavi A, Kwan G, van Baren MJ, Salzberg SL, Wold BJ \& Pachter L 2010 Transcript assembly and quantification by RNA-seq reveals unannotated transcripts and isoform switching during cell differentiation. Nature Biotechnology 28 511-515. (doi:10.1038/nbt.1621)

Truong AB, Kretz M, Ridky TW, Kimmel R \& Khavari PA 2006 p63 regulates proliferation and differentiation of developmentally mature keratinocytes. Genes and Development 20 3185-3197. (doi:10.1101/gad. 1463206)

Yallowitz AR, Alexandrova EM, Talos F, Xu S, Marchenko ND \& Moll UM 2014 p63 is a prosurvival factor in the adult mammary gland during post-lactational involution, affecting PI-MECs and ErbB2 tumorigenesis. Cell Death and Differentiation 21 645-654. (doi:10.1038/ cdd.2013.199)

Yamaji D, Na R, Feuermann Y, Pechhold S, Chen W, Robinson GW \& Hennighausen L 2009 Development of mammary luminal progenitor cells is controlled by the transcription factor STAT5A. Genes and Development 23 2382-2387. (doi:10.1101/gad.1840109)

Yamaji D, Kang K, Robinson GW \& Hennighausen L 2013 Sequential activation of genetic programs in mouse mammary epithelium during pregnancy depends on STAT5A/B concentration. Nucleic Acids Research 41 1622-1636. (doi:10.1093/nar/gks1310)

Yang A \& McKeon F 2000 P63 and P73: P53 mimics, menaces and more. Nature Reviews. Molecular Cell Biology 1 199-207. (doi:10.1038/ 35043127)

Yang A, Kaghad M, Wang Y, Gillett E, Fleming MD, Dotsch V, Andrews NC, Caput D \& McKeon F 1998 p63, a p53 homolog at 3q27-29, encodes multiple products with transactivating, death-inducing, and dominant-negative activities. Molecular Cell 2 305-316. (doi:10.1016/ S1097-2765(00)80275-0)

Yang A, Schweitzer R, Sun D, Kaghad M, Walker N, Bronson RT, Tabin C, Sharpe A, Caput D, Crum C et al. 1999 p63 is essential for regenerative proliferation in limb, craniofacial and epithelial development. Nature 398 714-718. (doi:10.1038/19539)

Yao JY \& Chen JK 2012 Roles of p63 in epidermal development and tumorigenesis. Biomedical Journal 35 457-463. (doi:10.4103/2319-4170. 104410)

Zhang Y, Laz EV \& Waxman DJ 2012 Dynamic, sex-differential STAT5 and BCL6 binding to sex-biased, growth hormone-regulated genes in adult mouse liver. Molecular and Cellular Biology 32 880-896. (doi:10.1128/ MCB.06312-11)

Received in final form 14 March 2014

Accepted 31 March 2014

Made available online as an Accepted Preprint

1 April 2014 http://erc.endocrinology-journals.org DOI: 10.1530/ERC-14-0032
(C) 2014 Society for Endocrinology Printed in Great Britain
Published by Bioscientifica Ltd 